Research Paper

\title{
Global DNA Methylation, Measured by the Lumino- metric Methylation Assay (LUMA), Associates with Postmenopausal Breast Cancer in Non-Obese and Physically Active Women
}

\author{
Lauren E. McCullough ${ }^{1 凶}$, Jia Chen ${ }^{2,3,4}$, Alexandra J. White ${ }^{1}$, Xinran $\mathrm{Xu}^{5}$, Yoon Hee Cho ${ }^{6}$, Patrick T.
} Bradshaw ${ }^{7}$, Sybil M. Eng8, Susan L. Teitelbaum², Mary Beth Terry ${ }^{8}$, Gail Garbowski ${ }^{6}$, Alfred I. Neugut ${ }^{8,9}$, Hanina Hibshoosh ${ }^{10}$, Regina M. Santella ${ }^{6}$ and Marilie D. Gammon ${ }^{1}$

1. Department of Epidemiology, University of North Carolina at Chapel Hill, Chapel Hill, NC, USA

2. Department of Preventive Medicine, Icahn School of Medicine at Mount Sinai, New York, NY, USA

3. Department of Pediatrics, Icahn School of Medicine at Mount Sinai, New York, NY, USA

4. Department of Oncological Science, Icahn School of Medicine at Mount Sinai, New York, NY, USA

5. Research Center for Translational Medicine, Shanghai East Hospital of Tongji University School of Medicine, Shanghai, China

6. Department of Environmental Health Sciences, Columbia University, New York, NY, USA

7. Department of Nutrition, University of North Carolina at Chapel Hill, Chapel Hill, NC, USA

8. Department of Epidemiology, Columbia University, New York, NY, USA

9. Department of Medicine, Columbia University, New York, NY, USA

10. Department of Pathology, Columbia University, New York, NY, USA

$\triangle$ Corresponding author: Lauren E. McCullough, Department of Epidemiology, CB \#7435, McGavran-Greenberg Hall, University of North Carolina, Chapel Hill, NC 27599-7435, USA. Phone: (919) 843-2321. Fax: (919) 966-2089. Email: lauren.mccullough@unc.edu

() 2015 Ivyspring International Publisher. Reproduction is permitted for personal, noncommercial use, provided that the article is in whole, unmodified, and properly cited. See http://ivyspring.com/terms for terms and conditions.

Received: 2014.12.16; Accepted: 2015.02.07; Published: 2015.05.01

\begin{abstract}
Introduction: Little is known about how modifiable lifestyle factors interact with the epigenome to influence disease. Body mass index (BMI, weight $\mathrm{kg} / \mathrm{height} \mathrm{m} 2$ ) and physical activity are associated with postmenopausal breast cancer, but the mechanisms are not well-understood. We hypothesized that BMI or physical activity may modify the association between markers of global DNA methylation and postmenopausal breast cancer risk.

Methods: Resources from a population-based case-control study ( 1300 postmenopausal women) were used to construct logistic regression models. We explored whether the association between breast cancer and global methylation, assessed using the luminometric methylation assay (LUMA) and long interspersed elements-1 (LINE-1) methylation in white blood cell DNA, was modified by BMI or recreational physical activity (RPA).

Results: The LUMA-breast cancer association was modified by BMI (multiplicative $p=0.03$ ) and RPA $(p=0.004)$. Non-obese women in the highest quartile of LUMA experienced a greater than two-fold increased risk of postmenopausal breast cancer $(\mathrm{BMI}<25 \mathrm{~kg} / \mathrm{m} 2$ : $\mathrm{OR}=2.16 ; 95 \% \mathrm{Cl}=1.35,3.57$ and $\mathrm{BMI}$ $25-29.9 \mathrm{~kg} / \mathrm{m} 2: \mathrm{OR}=2.96 ; 95 \% \mathrm{Cl}=1.69,5.19)$ compared to women in the lowest LUMA quartile. Similar increases in the LUMA-breast cancer association were observed among women who were physically active (moderate RPA: $\mathrm{OR}=2.62 ; 95 \% \mathrm{Cl}=1.44,4.75$ and high RPA: $\mathrm{OR}=2.62 ; 95 \% \mathrm{Cl}=1.53$, 4.49). Estimates among obese and inactive women were less pronounced and imprecise. Although we observed statistical interactions $(p<0.05)$ between BMI and RPA with LINE-1, we were unable to discern any clear associations with breast cancer.
\end{abstract}

Conclusions: The association between LUMA and postmenopausal breast cancer risk may be modified by postmenopausal body size and physical activity.

Key words: Obesity, physical activity, global DNA methylation, breast cancer, epidemiology 


\section{Introduction}

Breast cancer remains the leading cause of cancer-related illness in the United States, and is thought to be the result of both abnormal genetic and epigenetic change (1). DNA methylation is an epigenetic modification that may influence cancer development by altering gene expression and genome integrity (2). While gene-specific methylation in target tissue has been investigated widely, global hypomethylation in peripheral blood DNA has been related to the cancer genome (3) and may be a useful surrogate biomarker for studying lifestyle or environmental effects in large epidemiologic studies where tumor tissue is limited. Although global loss of DNA methylation can lead to genomic instability, alter gene transcription, and increase mutation rates (4), little is known about how modifiable lifestyle factors influence DNA methylation status of the genome (5).

Elevated body mass and physical inactivity have long been associated with increased risk of postmenopausal breast cancer $(6,7)$. Both have been shown to be associated with markers of global methylation in some studies, likely though their downstream effects on hormones and inflammation (8-11). Lifestyle factors may therefore play an important role in the association between global methylation and breast cancer risk.

The goals of this study were two-fold. We aimed to examine potential modification of the global DNA methylation-breast cancer association by (1) body size and (2) physical activity using two independent, but complementary, methods to assess global methylation in white blood cell (WBC) DNA: long interspersed elements-1 (LINE-1) methylation and the luminometric methylation assay (LUMA). LINE-1 methylation approximates levels in repetitive elements (12) and is a commonly used surrogate marker of genome-wide DNA hypomethylation (13), while LUMA measures levels of $5-\mathrm{m} C$ in the $\mathrm{C}^{\mathrm{m}} \mathrm{CGG}$ motif therefore approximating methylation levels at gene promoters rather than the total genome (14). We hypothesized that body size/physical activity would modify the association between global DNA methylation and postmenopausal breast cancer risk. To our knowledge, this is the first study to systematically address the interplay between body size or physical activity, DNA methylation and postmenopausal breast cancer risk using both LUMA and LINE 1.

\section{Materials and Methods}

We utilized resources from the case-control component of the Long Island Breast Cancer Study Project (LIBCSP), a population-based study. Details of the parent study have been reported previously (15).
Institutional Review Board approval was obtained by all participating institutions.

\section{Study population}

LIBCSP participants were English-speaking female residents of Nassau and Suffolk counties, Long Island, New York. LIBCSP case women were newly diagnosed with a first primary breast cancer between August 1, 1996 and July 31, 1997, and were identified through daily or weekly contact with local hospital pathology departments. Population-based controls were randomly selected using random digit dialing for women under age 65 and Health Care Finance Administration rosters for women ages 65 and older. LIBCSP controls were frequency matched to the expected age distribution of case women by 5-year age groups. At diagnosis/date of identification, participants were aged $20-98$ years, $67 \%$ were postmenopausal and $94 \%$ were white.

Interviews were completed for $82.1 \%(n=1508)$ of eligible cases and $62.8 \%(n=1556)$ of controls, and occurred within 3 months of diagnosis (before completion of the first course of treatment) for most case participants (15). At the time of the case-control interview, trained phlebotomists obtained a non-fasting $40 \mathrm{~mL}$ blood sample from $73.1 \%$ of case and $73.3 \%$ of control participants. DNA was isolated from blood specimens using the methods previously described (16). Written informed consent was obtained from all participants prior to the study interview.

\section{Global Methylation}

LUMA assessment in the LIBCSP has been described in detail (14) and followed the modified protocol described by Bjornsson et al. (17). LUMA levels were expressed as a percentage based on the following equation: methylation $(\%)=[1-($ HpaII $\Sigma \mathrm{G} / \Sigma \mathrm{T}) /(M s p \mathrm{I} \Sigma \mathrm{G} / \Sigma \mathrm{T})]^{\star} 100(17,17)$. LINE-1 methylation profiling for the LIBCSP has also been described in detail (14). A pre-validated pyrosequencing-based methylation assay $(18,19)$ was used to assess 4 CpG sites in the promoter region of LINE-1. Methylation status at each of the 4 loci were analyzed individually as a $\mathrm{T} / \mathrm{C}$ single nucleotide polymorphism using QCpG software (Qiagen) and subsequently averaged to provide an overall percentage $5^{\mathrm{m} C}$ status. For quality control randomly selected samples were replicated to examine batch effects (corresponding CV\% $<1 \%)$. Additionally, cases and controls were assayed at the same time with laboratory personnel blinded to both case-control and quality control status.

\section{Body Size, Physical Activity and Covariate Assessment}

Body size and physical activity were assessed as part of the interviewer-administered structured ques- 
tionnaire. Body mass index (BMI) at reference date was calculated for each participant based on the following formula: weight $(\mathrm{kg}) /$ height $\left(\mathrm{m}^{2}\right)$. Recreational physical activity (RPA) was assessed using a modified instrument developed by Bernstein and colleagues (20). RPA from menopause to reference date was used to estimate postmenopausal physical activity as previously described (21).

During the baseline interview participants were also asked about their demographic characteristics; reproductive, menstrual, environmental, and medical histories (including family history of breast cancer); cigarette smoking and alcohol use; and use of exogenous hormones.

\section{Statistical Methods}

All statistical analyses were performed using SAS statistical software version 9.1 (SAS Institute, Cary, NC).

The relationship between LUMA and LINE-1 global methylation in WBC DNA and breast cancer incidence has been previously reported among all women in the LIBCSP study population, regardless of menopausal status (14). Because this investigation focuses on postmenopausal breast cancer only, where associations with BMI and RPA are most relevant, we first estimated associations between LUMA, LINE-1 and breast cancer incidence among postmenopausal women only.

We subsequently assessed whether BMI or RPA was associated with global methylation levels measured in the blood of controls only. We conducted unconditional logistic regression to estimate odds ratios (ORs) and 95\% confidence intervals (CI) (22), with dichotomous global methylation markers as the outcome. We additionally used linear regression to estimate the association between BMI or RPA and global methylation levels.

Finally, we used a case-control approach to determine whether the association between global methylation (measured by LUMA and LINE-1) and postmenopausal breast cancer risk varied within strata of BMI or RPA. We conducted unconditional logistic regression (22) to estimate ORs and corresponding 95\% CIs for the joint effects of: (1) BMI and LUMA; (2) RPA and LUMA; (3) BMI and LINE-1; as well as (4) RPA and LINE-1, respectively. Multiplicative interaction was assessed by comparing multivariable models with and without cross-product terms to represent the interaction between BMI or RPA and the individual methylation marker (LUMA or LINE-1) using an a priori $\mathrm{p}<0.05$ (23). For case-control analyses methylation levels were categorized into quartiles based on the distribution among controls. Given LUMA, a global measurement of promoter methyla- tion, was positively associated with overall breast cancer risk in our study population (14) we used the lowest quartile as the referent group. In contrast, LINE-1 hypomethylation is hypothesized to represent decreased genomic integrity. Therefore the highest quartile of LINE-1 was selected as the referent category. We categorized BMI using the standard World Health Organization classifications $\left(<25.0 \mathrm{~kg} / \mathrm{m}^{2}\right.$; $25.0-29.9 \mathrm{~kg} / \mathrm{m}^{2}$; and $\geq 30 \mathrm{~kg} / \mathrm{m}^{2}$ ) and RPA based on the following definitions: inactive (no RPA), moderate RPA ( $\leq 9.23 \mathrm{hrs} / \mathrm{wk})$, and high RPA (>9.23 hrs/wk).

For all models, potential confounders included first degree family history of breast cancer (yes/no), history of benign breast disease (yes/no), race (white/black/other), use of oral contraceptives (ever/never), hormone replacement therapy (ever/never), age at menarche (continuous), parity (continuous), lactation history (ever/never), age at first birth (continuous), age at menopause (continuous), total daily calories (continuous), alcohol history (ever/never), and smoking history (never, current, former). Confounders were included in the final model if their inclusion changed the exposure estimate $>10 \%$ (24). None of the above covariates met our criterion and final models were adjusted only for 5-year age group.

\section{Results}

Table 1 shows the frequency (\%) of the key covariates used in our analyses (age, BMI, RPA, LUMA and LINE-1) by case control status among LIBCSP postmenopausal participants. LUMA levels were associated with increased risk of postmenopausal breast cancer (Quartile 4 [Q4] vs. Quartile 1 [Q1]: OR=2.20; 95\% CI=1.62, 3.00), whereas LINE-1 methylation levels were not (Q4 vs. Q1: OR=0.86; 95\% CI=0.64, 1.16).

In Table 2, we present the association between LUMA and postmenopausal breast cancer risk within strata of postmenopausal BMI and RPA, respectively. The association between LUMA and postmenopausal breast cancer risk was stronger among women with $\mathrm{BMI}<25(\mathrm{OR}=2.16 ; 95 \% \mathrm{CI}=1.35,3.47)$ or $\mathrm{BMI} 25-29$ (OR=2.96; 95\% CI=1.69, 5.19), compared to women with $\mathrm{BMI} \geq 30(\mathrm{OR}=1.46$; 95\% CI=0.78, 2.73) (multiplicative interaction $p=0.03$ ). Similarly, the association between LUMA and postmenopausal breast cancer risk was greater than 2-fold among women with low $(\mathrm{OR}=2.62 ; 95 \% \mathrm{CI}=1.53,4.49)$ and high $(\mathrm{OR}=2.62 ; 95 \%$ $\mathrm{CI}=1.44,4.75) \mathrm{RPA}$, whereas the association among inactive women was less in magnitude and included the null $(\mathrm{OR}=1.63 ; 95 \% \mathrm{CI}=0.86,3.11)$ (multiplicative interaction $p=0.004$ ).

We observed multiplicative interactions $(p<0.05)$ between LINE-1 methylation and both BMI and RPA, but our estimates were imprecise and we were unable 
to discern any clear patterns of association (Table 3). Furthermore, among control women neither postmenopausal BMI nor RPA were associated with LUMA in logistic or linear regression models (data not shown).

\section{Discussion}

In this population-based case-control study, we observed a greater than 2-fold increased risk of postmenopausal breast cancer when women in the highest quartile of LUMA were compared to women in the lowest. This association was modified by both BMI and RPA. LUMA was associated with the greatest risk of postmenopausal breast cancer among women with BMI $<30$ and among women who were physically active. Although we observed a significant multiplicative interaction $(\mathrm{p}<0.05)$ between LINE-1 and both BMI and RPA, we were unable to identify any clear relationship. We therefore conclude that, in our data, the association between LUMA and postmenopausal breast cancer risk is modified by both BMI and RPA.

To our knowledge, this is the first epidemiologic study to examine the association between genome-wide DNA methylation, assessed using LUMA, BMI or RPA and human cancer of any site. Lower global methylation can lead to genomic instability and changes in gene transcription which may impact normal cell growth and increase the likelihood of tumorigenesis (25). Given the cost and tissue specificity (26) of whole-genome methylation profiling, global methylation levels, assessed by LUMA, in readily available specimens (e.g. blood) may be feasible when studying lifestyle or environmental effects in large populations (27).
TABLE 1. Distributions of key covariates among postmenopausal cases and controls, Long Island Breast Cancer Study Project (1996-1997).

\begin{tabular}{|c|c|c|c|c|}
\hline & \multicolumn{2}{|c|}{ Cases } & \multicolumn{2}{|c|}{ Controls } \\
\hline & No & $\%$ & No & $\%$ \\
\hline \multicolumn{5}{|l|}{ Age at reference (years) ${ }^{a}$} \\
\hline$<40$ & 12 & 1.2 & 15 & 1.5 \\
\hline $40-44$ & 28 & 2.8 & 33 & 3.3 \\
\hline $45-49$ & 99 & 9.8 & 111 & 11.2 \\
\hline $50-54$ & 179 & 17.8 & 201 & 20.3 \\
\hline $55-59$ & 170 & 16.9 & 192 & 19.4 \\
\hline $60-64$ & 180 & 17.9 & 185 & 18.7 \\
\hline $65-69$ & 184 & 18.3 & 123 & 12.4 \\
\hline $70-74$ & 99 & 9.8 & 74 & 7.5 \\
\hline $75-79$ & 35 & 3.5 & 38 & 3.8 \\
\hline$\geq 80$ & 80 & 2.0 & 18 & 1.8 \\
\hline \multicolumn{5}{|l|}{ Body mass index (BMI)a } \\
\hline $\mathrm{BMI}\left(<25 \mathrm{~kg} / \mathrm{m}^{2}\right)$ & 386 & 39.0 & 439 & 45.3 \\
\hline BMI $\left(25-29.9 \mathrm{~kg} / \mathrm{m}^{2}\right)$ & 340 & 34.3 & 309 & 31.9 \\
\hline BMI $\left(\geq 30 \mathrm{~kg} / \mathrm{m}^{2}\right)$ & 264 & 26.7 & 222 & 22.9 \\
\hline \multicolumn{5}{|c|}{ Recreational physical activity (RPA)b } \\
\hline Inactive & 254 & 30.1 & 223 & 27.8 \\
\hline Low RPA $(\leq 9.23 \mathrm{hrs} / \mathrm{wk})$ & 329 & 38.9 & 290 & 36.1 \\
\hline High RPA (>9.23 hrs/wk) & 262 & 31.0 & 290 & 36.1 \\
\hline \multicolumn{5}{|l|}{ Luminometric methylation assayc } \\
\hline Quartile $1(<0.43)$ & 119 & 17.3 & 164 & 24.1 \\
\hline Quartile $2(0.43<0.56)$ & 126 & 18.3 & 177 & 26.0 \\
\hline Quartile $3(0.56<0.66)$ & 186 & 27.0 & 175 & 25.7 \\
\hline Quartile $4(\geq 0.66)$ & 259 & 37.5 & 165 & 24.2 \\
\hline \multicolumn{5}{|l|}{ Long interspersed elements- $1 \mathrm{c}$} \\
\hline Q4 ( $(\geq 80.4)$ & 186 & 26.7 & 156 & 22.8 \\
\hline Q3 (78.7<80.4) & 175 & 25.1 & 180 & 26.4 \\
\hline Q2 $(77.0<78.7)$ & 155 & 22.2 & 171 & 25.0 \\
\hline Q1 $(<77.0)$ & 182 & 26.1 & 176 & 25.8 \\
\hline
\end{tabular}

Adapted from Gammon et al. 2002a; McCullough et al.2012b; and Xu et al.c

TABLE 2. Age-adjusted odds ratios (ORs) and $95 \%$ confidence intervals ( $\mathrm{Cls}$ ) for the associations between the luminometric methylation assay (LUMA) methylation levels and postmenopausal breast cancer stratified by postmenopausal body mass index (BMI) and recreational physical activity (RPA, average hours per week) among cases (Ca) and controls (Co), Long Island Breast Cancer Study Project (1996-1997).

\begin{tabular}{|c|c|c|c|c|c|c|c|c|c|}
\hline LUMA (Quartiles) & $\mathrm{Ca}^{a} / \mathrm{Co}^{\mathrm{b}}$ & ORc & $95 \% \mathrm{CI}^{\mathrm{d}}$ & $\mathrm{Ca} / \mathrm{Co}$ & OR & $95 \% \mathrm{CI}$ & $\mathrm{Ca} / \mathrm{Co}$ & OR & $95 \% \mathrm{CI}$ \\
\hline & \multicolumn{9}{|c|}{ Body Mass Index } \\
\hline & \multicolumn{3}{|c|}{$\mathrm{BMI}^{\mathrm{e}}\left(<25 \mathrm{~kg} / \mathrm{m}^{2}\right)$} & \multicolumn{3}{|c|}{ BMI $\left(25-29.9 \mathrm{~kg} / \mathrm{m}^{2}\right)$} & \multicolumn{2}{|c|}{$\mathrm{BMI}\left(\geq 30 \mathrm{~kg} / \mathrm{m}^{2}\right)$} & \\
\hline $\mathrm{Q} 1(<0.43)$ & $48 / 77$ & 1.00 & reference & $32 / 50$ & 1.00 & reference & $38 / 34$ & 1.00 & reference \\
\hline Q2 $(0.43<0.56)$ & $48 / 80$ & 0.94 & $(0.56,1.56)$ & $41 / 55$ & 1.18 & $(0.65,2.16)$ & $35 / 40$ & 0.83 & $(0.43,1.60)$ \\
\hline Q3 $(0.56<0.66)$ & $66 / 84$ & 1.24 & $(0.76,2.02)$ & $62 / 54$ & 1.82 & $(1.02,3.25)$ & $57 / 35$ & 1.51 & $(0.80,2.85)$ \\
\hline \multirow{4}{*}{ Q4 ( $\geq 0.66)$} & $98 / 74$ & 2.16 & $(1.35,3.47)$ & $97 / 51$ & 2.96 & $(1.69,5.19)$ & $59 / 38$ & 1.46 & $(0.78,2.73)$ \\
\hline & \multicolumn{6}{|c|}{ multiplicative $p=0.033$} & & & \\
\hline & \multicolumn{6}{|c|}{ Recreational Physical Activity } & & & \\
\hline & \multicolumn{3}{|c|}{ High $\operatorname{RPA}^{\mathrm{f}}(>9.23 \mathrm{hrs} / \mathrm{wk})$} & \multicolumn{3}{|c|}{ Moderate RPA ( $\leq 9.23 \mathrm{hrs} / \mathrm{wk})$} & \multicolumn{2}{|l|}{ Inactive } & \\
\hline Q1 $(<0.43)$ & $27 / 51$ & 1.00 & reference & $43 / 54$ & 1.00 & reference & $31 / 33$ & 1.00 & reference \\
\hline Q2 $(0.43<0.56)$ & $32 / 65$ & 0.89 & $(0.47,1.69)$ & $44 / 47$ & 1.16 & $(0.65,2.06)$ & $38 / 38$ & 1.11 & $(0.57,2.18)$ \\
\hline Q3 $(0.56<0.66)$ & $54 / 43$ & 2.45 & $(1.31,4.59)$ & $51 / 50$ & 1.27 & $(0.72,2.23)$ & $48 / 43$ & 1.21 & $(0.63,2.33)$ \\
\hline \multirow[t]{2}{*}{ Q4 ( $\geq 0.66)$} & $72 / 53$ & 2.62 & $(1.44,4.75)$ & $92 / 46$ & 2.62 & $(1.53,4.49)$ & $59 / 39$ & 1.63 & $(0.86,3.11)$ \\
\hline & \multicolumn{3}{|c|}{ multiplicative $p=0.004$} & & & & & & \\
\hline
\end{tabular}

${ }^{\mathrm{a}}$ Cases; ${ }^{\mathrm{b}}$ Controls; ${ }^{\mathrm{C}}$ Odds ratio; ${ }^{\mathrm{d}}$ Confidence interval; $\mathrm{e}$ Body mass index; ${ }^{\mathrm{f}}$ Recreational physical activity 
TABLE 3. Age-adjusted odds ratios (ORs) and $95 \%$ confidence intervals ( $\mathrm{Cls}$ ) for the associations between long interspersed elements- 1 (LINE-1) methylation profiling and postmenopausal breast cancer stratified by postmenopausal body mass index (BMI) and recreational physical activity (RPA, average hours per week) among cases (Ca) and controls (Co), Long Island Breast Cancer Study Project (1996-1997).

\begin{tabular}{|c|c|c|c|c|c|c|c|c|c|}
\hline LINE-1 (Quartiles) & $\mathrm{Ca}^{\mathrm{a}} / \mathrm{Co}^{\mathrm{b}}$ & $\mathrm{OR}^{\mathrm{c}}$ & $95 \% \mathrm{CI}^{\mathrm{d}}$ & $\mathrm{Ca} / \mathrm{Co}$ & OR & $95 \% \mathrm{CI}$ & $\mathrm{Ca} / \mathrm{Co}$ & OR & $95 \% \mathrm{CI}$ \\
\hline & \multicolumn{9}{|c|}{ Body Mass Index } \\
\hline & \multicolumn{3}{|c|}{$\mathrm{BMIe}\left(<25 \mathrm{~kg} / \mathrm{m}^{2}\right)$} & \multicolumn{3}{|c|}{ BMI $\left(25-29.9 \mathrm{~kg} / \mathrm{m}^{2}\right)$} & \multicolumn{3}{|c|}{ BMI $\left(\geq 30 \mathrm{~kg} / \mathrm{m}^{2}\right)$} \\
\hline Q4 ( $\geq 80.4)$ & $69 / 79$ & 1.00 & reference & $62 / 50$ & 1.00 & reference & $51 / 44$ & 1.00 & reference \\
\hline Q3 $(78.7<80.4)$ & $58 / 81$ & 1.14 & $(0.72,1.79)$ & $47 / 61$ & 0.64 & $(0.37,1.09)$ & $46 / 26$ & 1.46 & $(0.77,2.75)$ \\
\hline Q2 (77.0<78.7) & $63 / 78$ & 0.93 & $(0.58,1.47)$ & $63 / 55$ & 0.95 & $(0.56,1.61)$ & $44 / 45$ & 0.85 & $(0.47,1.52)$ \\
\hline Q1 $(<77.0)$ & $75 / 76$ & 1.14 & $(0.72,1.79)$ & $60 / 46$ & 1.10 & $(0.64,1.89)$ & $51 / 33$ & 1.30 & $(0.71,2.38)$ \\
\hline
\end{tabular}

Q4 ( $\geq 80.4)$

Q3 $(78.7<80.4)$

Q2 $(77.0<78.7)$

Q1 $(<77.0)$ multiplicative $p=0.014$

Recreational Physical Activity High RPAf (>9.23 hrs/wk)

$51 / 50 \quad 1.00 \quad$ reference

$47 / 61 \quad 0.86 \quad(0.48,1.54)$

$43 / 55 \quad 0.76 \quad(0.43,1.34)$

$45 / 46 \quad 1.05 \quad(0.59,1.86)$

multiplicative $p=0.049$
Moderate RPA ( $\leq 9.23 \mathrm{hrs} / \mathrm{wk})$

$67 / 48 \quad 1.00 \quad$ reference

$60 / 48 \quad 1.07 \quad(0.62,1.85)$

$55 / 51 \quad 1.27 \quad(0.74,2.19)$

$50 / 51 \quad 1.42 \quad(0.83,2.43)$

$\begin{array}{lll}\begin{array}{l}\text { Inactive } \\ 46 / 33\end{array} & 1.00 & \text { reference } \\ 44 / 42 & 0.54 & (0.29,1.02) \\ 30 / 39 & 0.74 & (0.41,1.34) \\ 58 / 41 & 0.97 & (0.53,1.77)\end{array}$

a Cases; ${ }^{\mathrm{b}}$ Controls; $\mathrm{c}$ Odds ratio; ${ }^{\mathrm{d}}$ Confidence interval; $\mathrm{e}$ Body mass index; ${ }^{\mathrm{f}}$ Recreational physical activity

A number of investigations have evaluated associations between biomarkers of global methylation and other cancer types, but less is known about the effect of global methylation in breast cancer, particularly with LUMA (reviewed in (28)). Delgado-Cruzata (29) reported no difference in methylation levels by LUMA between affected and unaffected sisters, while a recent hospital-based case control study conducted in a Japanese population showed breast cancer risk reductions with increasing tertiles of LUMA methylation (30). These results are in contrast to what was observed in our study population, namely that women in the highest quintile of LUMA had increased risk of breast cancer $(\mathrm{OR}=2.14 ; 95 \% \mathrm{CI}=1.83$, 3.16; $p$ trend < 0.0001) compared to women in the lowest quintile (14). The same report (14) found no association with LINE-1, which is consistent with the results of a recent meta-analysis that considered all cancer outcomes (28).

Further, there are inconsistencies in associations between both BMI and physical activity with LINE-1. Elevated BMI has been shown to be associated with lower LINE-1 methylation some studies $(8,9)$ but was not correlated with LINE-1 in others $(31,32)$. Regarding physical activity, some studies show associations between exercise and LINE-1 $(10,11)$, while others do not (33). Given the unclear associations between BMI or physical activity and LINE-1, as well as the uncertainty of LINE-1 methylation as a useful biomarker in epidemiologic studies of cancer (28), our findings for LINE-1 are not unexpected. While our observations for LUMA support our a priori hypothesis of modification by both BMI and physical activity, we anticipated that the positive association between LUMA and postmenopausal breast cancer risk would be strongest among women with elevated BMI and/or inactive lifestyle. On the contrary, our data showed that high LUMA levels were more strongly associated with enhanced postmenopausal breast cancer risk among active women and women with $\mathrm{BMI}<30 \mathrm{~kg} / \mathrm{m}^{2}$. Obesity/inactivity is associated with a myriad of health consequences - many of which may not be mediated by changes in DNA methylation. We anticipate that our seemingly paradoxical results may be because obese women in the lowest quartile of LUMA (Q1) are already at enhanced risk of postmenopausal breast cancer. Any additional risk caused by aberrant DNA methylation may therefore be minimal. In contrast, women with BMI $<25 \mathrm{~kg} / \mathrm{m}^{2}$ or high levels of physical activity have a baseline risk of breast cancer that is relatively low (as compared with women who are overweight/obese or those with lower levels of physical activity). Thus, any additional risk caused by aberrant methylation, may be substantial enough to enhance overall susceptibility to postmenopausal breast cancer among those women who are at lower risk of breast cancer.

Strengths of our study include is its population-based design; relatively large sample size; as well as detailed exposure assessment. While anthropometric data were collected systematically by trained interviewers (15) errors in reporting or differential reporting by cases and controls have the potential to bias the study results. However, is unlikely that misreporting is differential with respect to methylation status (34). While there is interest in identifying epigenetic markers in surrogate tissue that could be used to identify high risk populations, it is unknown whether these markers truly reflect the epignome or gene regulation in the target tissue. Some studies indicate that blood-derived DNA methylation measurements (e.g. LINE-1) do not correlate with methyl- 
ation in tumor tissue $(31,35,36)$, but additional investigations are needed to understand the correlation between target and surrogate tissues using other assays, particularly LUMA.

Using data from a large population-based sample, we observed that high methylation levels, assessed via the LUMA, were inversely associated with postmenopausal breast cancer among active and non-obese women. While our results require confirmation, they suggest that body size or physical activity may play an important role in modifying the association between DNA methylation and postmenopausal breast cancer. Given the plasticity of epigenetic marks in response to cancer-related exposures, additional research is needed to clarify these mechanisms and identify specific changes likely to be involved in the pathogenesis of breast cancer.

\section{Abbreviations}

BMI: Body mass index; CI: confidence interval; LIBCSP: Long Island Breast Cancer Study Project; LINE-1: long interspersed elements-1; LUMA: luminometric methylation assay; OR: odds ratio; RPA: recreational physical activity; WBC: white blood cell.

\section{Acknowledgements}

This work was supported, in part, by grants from the the National Cancer Institute at the National Institutes of Health [Grant numbers R25CA057726, UO1CA/ES66572, R01CA109753 and 3R01CA10975304S1]; the National Institutes of Environmental Health and Sciences [P30ES009089 and P30ES10126]; and the Department of Defense [BC031746, BC972772 and W81XWH-06-1-0298].

\section{Conflicts of Interest}

None to declare.

\section{References}

1. Russo J, Yang X, Hu YF, Bove BA, Huang Y, Silva ID, Tahin Q, Wu Y, Higgy N, Zekri A, Russo IH. Biological and molecular basis of human breast cancer. Front Biosci 1998 Sep 1;3:D944-60.

2. Jones PA, Baylin SB. The fundamental role of epigenetic events in cancer. Nat Rev Genet 2002 Jun;3(6):415-428.

3. Wilson AS, Power BE, Molloy PL. DNA hypomethylation and human diseases. Biochim Biophys Acta 2007 Jan;1775(1):138-162.

4. Chen RZ, Pettersson U, Beard C, Jackson-Grusby L, Jaenisch R. DNA hypomethylation leads to elevated mutation rates. Nature 1998 Sep 3;395(6697):89-93.

5. Ulrich CM, Grady WM. Linking epidemiology to epigenomics--where are we today? Cancer Prev Res (Phila) 2010 Dec;3(12):1505-1508.

6. Friedenreich CM. Review of anthropometric factors and breast cancer risk. Eur J Cancer Prev 2001 Feb;10(1):15-32.

7. Friedenreich CM. Physical activity and breast cancer: review of the epidemiologic evidence and biologic mechanisms. Recent Results Cancer Res 2011;188:125-139.

8. Feinberg AP, Irizarry RA, Fradin D, Aryee MJ, Murakami P, Aspelund T, Eiriksdottir G, Harris TB, Launer L, Gudnason V, Fallin MD. Personalized epigenomic signatures that are stable over time and covary with body mass index. Sci Transl Med 2010 Sep 15;2(49):49ra67.

9. Piyathilake C, Badiga S, Johanning G, Alvarez R, Partridge E. Predictors and health consequences of epigenetic changes associated with excess body weight in women of child-bearing age. Cancer Epidemiol Biomarkers Prev 2011;:719.
10. White AJ, Sandler DP, Bolick SC, Xu Z, Taylor JA, Deroo LA. Recreational and household physical activity at different time points and DNA global methylation. Eur J Cancer 2013 Jun;49(9):2199-2206.

11. Zhang FF, Cardarelli R, Carroll J, Zhang S, Fulda KG, Gonzalez K, Vishwanatha JK, Morabia A, Santella RM. Physical activity and global genomic DNA methylation in a cancer-free population. Epigenetics 2011 Mar;6(3):293-299.

12. Weisenberger DJ, Campan M, Long TI, Kim M, Woods C, Fiala E, Ehrlich M, Laird PW. Analysis of repetitive element DNA methylation by MethyLight. Nucleic Acids Res 2005 Dec 2;33(21):6823-6836.

13. Yang AS, Estecio MR, Doshi K, Kondo Y, Tajara EH, Issa JP. A simple method for estimating global DNA methylation using bisulfite PCR of repetitive DNA elements. Nucleic Acids Res 2004 Feb 18;32(3):e38.

14. Xu X, Gammon MD, Hernandez-Vargas H, Herceg Z, Wetmur JG, Teitelbaum SL, Bradshaw PT, Neugut AI, Santella RM, Chen J. DNA methylation in peripheral blood measured by LUMA is associated with breast cancer in a population-based study. FASEB J 2012 Feb 27.

15. Gammon MD, Neugut AI, Santella RM, Teitelbaum SL, Britton JA, Terry MB, Eng SM, Wolff MS, Stellman SD, Kabat GC, Levin B, Bradlow HL, et al. The Long Island Breast Cancer Study Project: description of a multi-institutional collaboration to identify environmental risk factors for breast cancer. Breast Cancer Res Treat 2002 Jun;74(3):235-254.

16. Gammon MD, Santella RM, Neugut AI, Eng SM, Teitelbaum SL, Paykin A, Levin B, Terry MB, Young TL, Wang LW, Wang Q, Britton JA, et al. Environmental toxins and breast cancer on Long Island. I. Polycyclic aromatic hydrocarbon DNA adducts. Cancer Epidemiol Biomarkers Prev 2002 Aug;11(8):677-685.

17. Bjornsson HT, Sigurdsson MI, Fallin MD, Irizarry RA, Aspelund T, Cui H, Yu W, Rongione MA, Ekström TJ, Harris TB, Launer LJ, Eiriksdottir G, et al. Intra-individual change over time in DNA methylation with familial clustering. JAMA 2008 Jun 25;299(24):2877-2883.

18. McShane LM, Altman DG, Sauerbrei W, Taube SE, Gion M, Clark GM, Statistics Subcommittee of NCI-EORTC Working Group on Cancer Diagnostics. REporting recommendations for tumor MARKer prognostic studies (REMARK). Breast Cancer Res Treat 2006 Nov;100(2):229-235.

19. Eads CA, Danenberg KD, Kawakami K, Saltz LB, Danenberg PV, Laird PW. $\mathrm{CpG}$ island hypermethylation in human colorectal tumors is not associated with DNA methyltransferase overexpression. Cancer Res 1999 May 15;59(10):2302-2306.

20. Bernstein M, Sloutskis D, Kumanyika S, Sparti A, Schutz Y, Morabia A. Data-based approach for developing a physical activity frequency questionnaire. Am J Epidemiol 1998 Jan 15;147(2):147-154.

21. McCullough LE, Eng SM, Bradshaw PT, Cleveland RJ, Teitelbaum SL, Neugut AI, Gammon MD. Fat or fit: The joint effects of physical activity, weight gain, and body size on breast cancer risk. Cancer 2012 Oct 1;118(19):4860-4868.

22. Kleinbaum DG, Klein M. Logistic Regression: A Self-Learning Text. 2nd ed. New York: Springer; 2002.

23. Breslow NE, Day NE. Statistical methods in cancer research. Volume I - The analysis of case-control studies. IARC Sci Publ 1980;:5-338.

24. Greenland S. Modeling and variable selection in epidemiologic analysis. Am J Public Health 1989 Mar;79(3):340-349.

25. Terry MB, Delgado-Cruzata L, Vin-Raviv N, Wu HC, Santella RM. DNA methylation in white blood cells: association with risk factors in epidemiologic studies. Epigenetics 2011 Jul;6(7):828-837.

26. Christensen BC, Houseman EA, Marsit CJ, Zheng S, Wrensch MR, Wiemels JL, Nelson HH, Karagas MR, Padbury JF, Bueno R, Sugarbaker DJ, Yeh RF, et al. Aging and environmental exposures alter tissue-specific DNA methylation dependent upon CpG island context. PLoS Genet 2009 Aug;5(8):e1000602.

27. Hsiung DT, Marsit CJ, Houseman EA, Eddy K, Furniss CS, McClean MD, Kelsey KT. Global DNA methylation level in whole blood as a biomarker in head and neck squamous cell carcinoma. Cancer Epidemiol Biomarkers Prev 2007 Jan;16(1):108-114.

28. Brennan K, Flanagan JM. Is there a link between genome-wide hypomethylation in blood and cancer risk? Cancer Prev Res (Phila) 2012 Dec;5(12):1345-1357.

29. Delgado-Cruzata L, Wu HC, Perrin M, Liao Y, Kappil MA, Ferris JS, Flom JD, Yazici H, Santella RM, Terry MB. Global DNA methylation levels in white blood cell DNA from sisters discordant for breast cancer from the New York site of the Breast Cancer Family Registry. Epigenetics 2012 Aug;7(8):868-874.

30. Kuchiba A, Iwasaki M, Ono H, Kasuga Y, Yokoyama S, Onuma H, Nishimura $\mathrm{H}$, Kusama R, Tsugane S, Yoshida T. Global methylation levels in peripheral blood leukocyte DNA by LUMA and breast cancer: a case-control study in Japanese women. Br J Cancer 2014 May 27;110(11):2765-2771.

31. Zhu ZZ, Hou L, Bollati V, Tarantini L, Marinelli B, Cantone L, Yang AS, Vokonas P, Lissowska J, Fustinoni S, Pesatori AC, Bonzini M, et al. Predictors of global methylation levels in blood DNA of healthy subjects: a combined analysis. Int J Epidemiol 2012 Feb;41(1):126-139.

32. Kim KY, Kim DS, Lee SK, Lee IK, Kang JH, Chang YS, Jacobs DR, Steffes M, Lee DH. Association of low-dose exposure to persistent organic pollutants with global DNA hypomethylation in healthy Koreans. Environ Health Perspect 2010 Mar;118(3):370-374.

33. Zhang FF, Santella RM, Wolff M, Kappil MA, Markowitz SB, Morabia A. White blood cell global methylation and IL-6 promoter methylation in association with diet and lifestyle risk factors in a cancer-free population. Epigenetics 2012 Jun 1;7(6):606-614

34. Terry MB, Gammon MD, Zhang FF, Eng SM, Sagiv SK, Paykin AB, Wang Q, Hayes S, Teitelbaum SL, Neugut AI, Santella RM. Polymorphism in the DNA 
repair gene $\mathrm{XPD}$, polycyclic aromatic hydrocarbon-DNA adducts, cigarette smoking, and breast cancer risk. Cancer Epidemiol Biomarkers Prev 2004 Dec;13(12):2053-2058.

35. Piyathilake CJ, Macaluso M, Alvarez RD, Chen M, Badiga S, Siddiqui NR, Edberg JC, Partridge EE, Johanning GL. A higher degree of LINE-1 methylation in peripheral blood mononuclear cells, a one-carbon nutrient related epigenetic alteration, is associated with a lower risk of developing cervical intraepithelial neoplasia. Nutrition 2011 May;27(5):513-519.

36. van Bemmel D, Lenz P, Liao LM, Baris D, Sternberg LR, Warner A, Johnson A, Jones M, Kida M, Schwenn M, Schned AR, Silverman DT, et al. Correlation of LINE-1 methylation levels in patient-matched buffy coat, serum, buccal cell, and bladder tumor tissue DNA samples. Cancer Epidemiol Biomarkers Prev 2012 Jul;21(7):1143-1148. 